\title{
Menteşe yöntemleri ve osteotomi felsefesi
}

\author{
Philosophy of osteotomy and hinge types
}

\author{
Halil İbrahim Balcı ${ }^{1}$, Sevan Sıvacıoğlư ${ }^{2}$, Alper Şükrü Kendirci ${ }^{1}$ \\ ${ }^{1}$ İstanbul Üniversitesi İstanbul Tıp Fakültesi, Ortopedi ve Travmatoloji Anabilim Dalı, İstanbul \\ ${ }^{2}$ Acıbadem Üniversitesi Sağlık Bilimleri Fakültesi, İstanbul
}

\begin{abstract}
Kemiği cerrahi müdahale ile düzeltme amacı ile kesme anlamına gelen osteotominin etkilerini standardize etmek için osteotomi kuralları belirlenmiştir. Bu kurallar özellikle distraksiyon osteogenezi ve ílizarov prensiplerinden etkilenmiş ve tıp literatüründeki gelişimlerini sürdürmüşlerdir. ACA, CORA ve açı ortay hattının ne olduğunu anlamak, bunları tanımak ve bunlarda olacak değişikliklerin nasıl sonuçlar doğuracağını bilmek amaçlanan tedavinin planlanmasında önemlidir. Her ne kadar geçtiğimiz birkaç yılda yüksek hasta konforu sebepli internal fiksasyon daha popüler olsa da kurtarma prosedürlerinden olan ve özellikle ekstremiteleri koruyan eksternal fiksatörlerin temel ilkerini bilmek, menteşe ve motor ünitesi ile tedrici düzeltmelerden haberdar olmak oldukça önemlidir.
\end{abstract}

Anahtar sözcükler: osteotomi kuralları; tedrici düzeltme; menteşe
Osteotomy, a surgical operation that cut of the bone to correct the deformity, is standardised with the rules. They are especially developed after the distraction osteogenesis and Ilizarov's principles. It is important to understand what ACA, CORA and angle midway are, to recognize them and to know how the changes will have consequences, in the planning of the intended treatment. Althougth that internal fixation became more popular in the past few years because of the higher patient comfort, it is now much more important to know the basics of external fixators which save the limbs especially in the salvage procedures, such as hinges, motor unit and gradual correction.

Key words: osteotomy rules; gradual correction; hinges

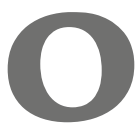

steotomi etimolojik olarak kemik ve kesmek kelimelerinin köklerinden gelmektedir. Anlam olarak ise kesme ve ayırma işlemlerini karşılar. Osteotomi işlemiyle hedeflerimiz üç planlı düzlemde; kısaltma, translasyon, açılanma, rotasyon, kompresyon veya distraksiyon yaratmak olabilir..$^{[1,2]}$

Kemiklerde rastgele yapılacak bir osteotomi ile ciddi zararlar verilebilir. Yumuşak dokuyu en az şekilde travmatize etmek, kemik beslenmesini ve iyileşmesini etkilememek için osteotomi özenle yapılmalıdır. Periosteal beslenme özellikle distraksiyon osteogenezinde elde edilen kemik iyileşmesi için önemlidir. ${ }^{[3-5]}$ Periostun sağlam kalması bu nedenle önemlidir. Kemiğin beslenmesinde önemli bir yer tutan yumuşak dokuların korunması dışında, deformitenin düzeltilmesi ile ilgili osteotomi kuralları mevcuttur. Ancak bu kurallar osteotominin ve sonraki düzeltmenin nasıl yapılacağı ile ilgilidir. ${ }^{[4]}$ Kompleks bir deformitenin tedavisinde yetersizlik ve başka deformitelere yol açmamak için bu kurallar iyi anlaşılmalıdır. Osteotomi kuralları ilk defa Dr. Paley tarafindan sistematize edilmiştir. ${ }^{[5]}$

Osteotomi kurallarını anlayabilmek için oluşturulan üç adet kavram mevcuttur.

1. CORA (Center of Rotation of Angulation - Açılanmanın Merkez Noktası)

2. ACA (Angulation Correction Axis - Açılanmayı Düzeltme Ekseni)

\section{Açı ortay çizgisi}

Bu üç değişkenden CORA her deformiteye göre değişken olmakla beraber planlama sırasında sabit kalır. ACA ve Osteotomi seviyesi cerraha ve tekniğe göre değişkenlik gösterir. ${ }^{[5-8]}$

- İletişim adresi: Doç. Dr. Halil İ. Balcı, ì.Ü. İstanbul Tıp Fakültesi Ortopedi ve Travmatoloji Anabilim Dalı, Millet Cad. No:118 Fatih 34093, İstanbul Tel: 0532 - 5124727 e-posta: balcihalili@gmail.com

- Geliș tarihi: 25 Kasım 2019 Kabul tarihi: 30 Ocak2020 


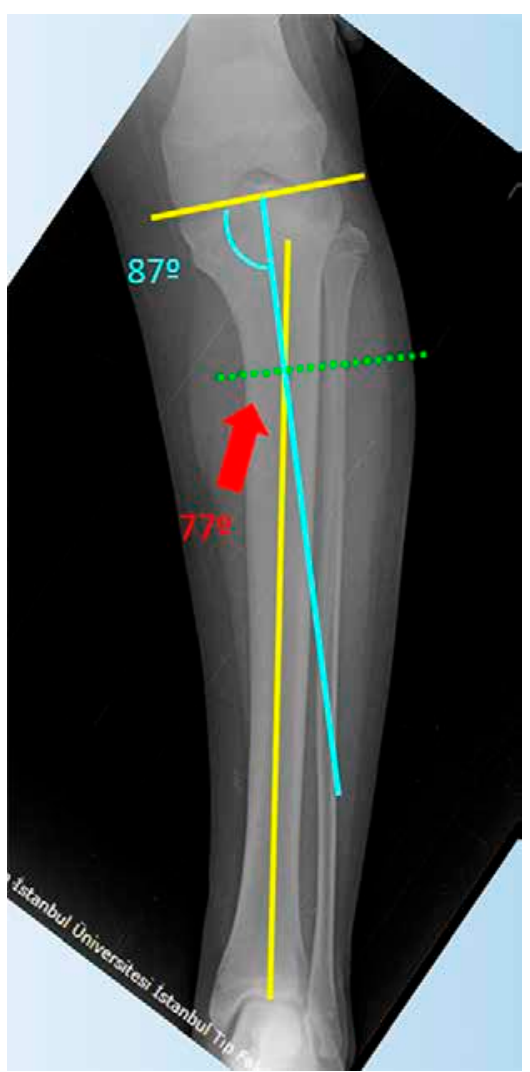

Şekil 1. CORA noktası; proksimal ve distal tibia mekanik akslarının tibia proksimal metafizinde açı oluşturarak kesiştiklerini görmekteyiz. Burası deformitenin tepe noktası, CORA'sıdır.

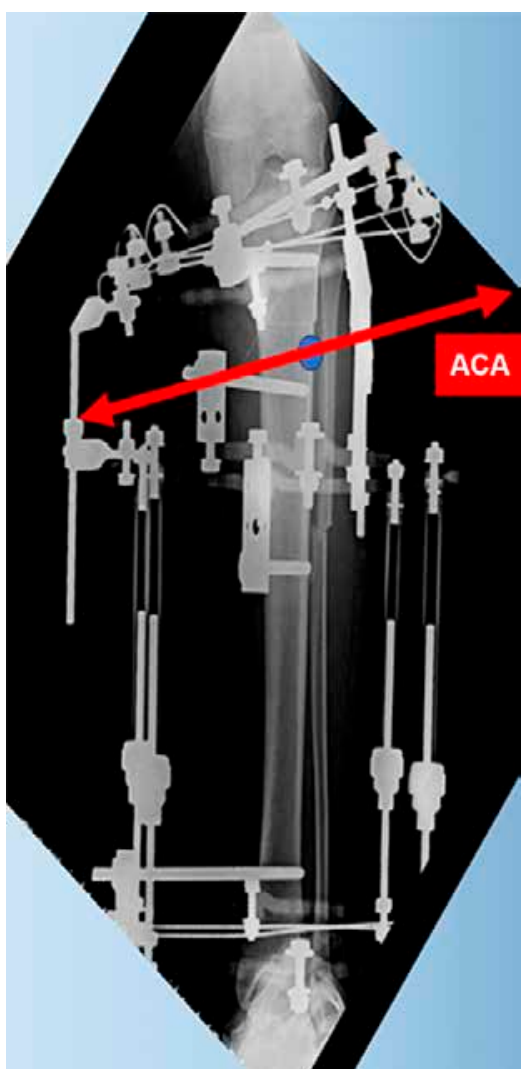

Şekil 2. ACA; deformitenin düzeltme aksı. Menteşe superpoze olarak çekilen grafide menteşe üzerinde mavi noktadan uzaya doğru ilerleyen z ekseni ACA olarak adlandırılır.

\section{CORA}

Center of Rotation of Angulation kelimelerinin baş harflerinden oluşmaktadır. Hem mekanik hem de anatomik aks (eksen) kullanılarak hesaplanabilir ve deformitenin tepe noktasını belirtir. Kemikte mevcut olan açısal deformitenin proksimal ve distal fragmanlarının akslarının (eksenlerinin) kesişim noktası deformitenin CORA'sı olarak nitelendirilir. ${ }^{[5-7]}$ CORA iki boyutlu düzlemde nokta ile ifade edilir (Şekil 1).

\section{ACA}

Angulation Correction Axis kelimelerinin baş harflerinden oluşmaktadır. Açılanmanın düzeltme aksını ifade eder. Deformitenin lokalizasyonunu veya yapısını değil, deformiteyi düzeltirken referans alınacak doğrultuyu gösterir. Bu sebeple cerraha ve kullanılacak yöntemlere bağlıdır. Özellikle İlizarov sistemlerinde menteşelerin yerleşim yeri ile yakından ilişkilidir. iki menteşe arasından geçen hayali çizgi bize ACA doğrultusunu verir. İki boyutlu şablonlarda nokta ile gösterilmesine rağmen üç boyutlu düzlemde yer alan bir çizgidir (Şekil 2). ${ }^{[5,7,9]}$

\section{Açı Ortay Çizgisi}

Kısaca transvers osteotomilerde osteotominin yapılması gereken doğrultuyu gösterir. Proksimal ve distal anatomik veya mekanik aksların kesişmesi ile ortaya çıkan açının tam ortasından geçen çizgidir.

Osteotomi ile ilgili iki ana unsur mevcuttur. Bunlar osteotominin yeri ve osteotominin şeklidir. ${ }^{[5]}$

Kullanılacak olan tespit yöntemleri, deformitenin şekli, fiz hattının varlığı, ligament ve tendonların yapışma yerleri, kemik kalitesi ve yumuşak doku durumu osteotominin yerini ve şeklini belirleyen önemli faktörlerdir. Diğer bir deyişle osteotomi ya CORA noktasında ya da CORA noktası dışında olur. Osteotomi; transvers, oblik veya kubbe şekilde olabilir. Önemli olan osteotominin şeklinden ziyade lokalizasyonudur. Amaçlanan osteotomi açık kama veya kapalı kama şeklinde olabileceği gibi nötral osteotomi de yapılabilir. Burda belirleyici olan hastada gerekli olabilen uzunluk veya kısalık ihtiyacıdır. Kubbe osteotomisi özellikle translasyonun fazla verilmesi gereken durumlarda yumuşak doku ve kemik arasındaki ilişkiyi kaybetmemek adına avantaj sağlar. Daha az translasyonla daha fazla 


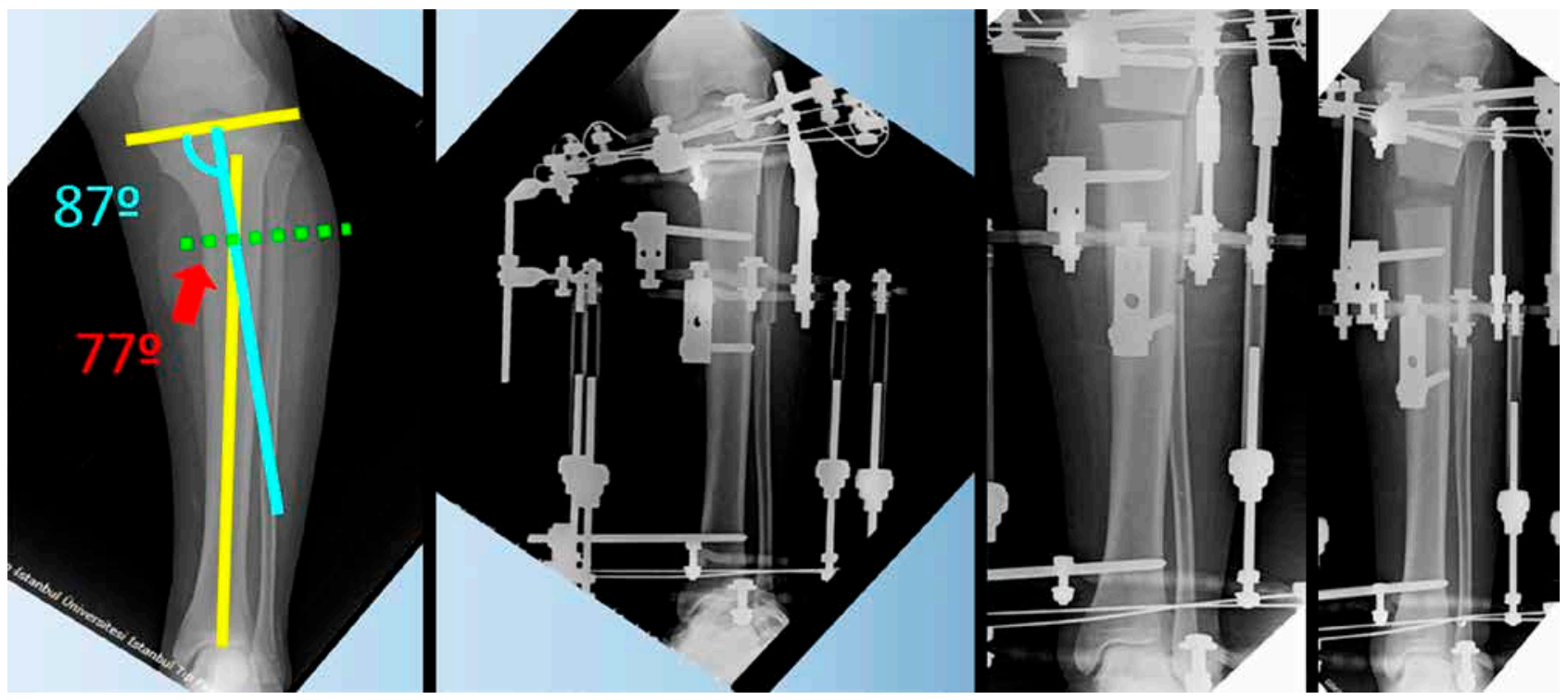

Şekil 3. Açık Kama Osteotomisi: Tibia proksimalinde varus deformitesi ve kısalığı olan hastada yapılan tibia proksimal osteotomisi ve menteşelerin konkav tarafa ACA ekseninde yerleştirilmesi ile düzeltme ve uzatma elde edilmiştir. Elde edilen uzatma hastada ekstremite uzunluk farkını ortadan kaldırmadığı için hastaya distraksiyon rodları konarak ekstra uzatma sağlanmıştır.

derecede deformite düzeltmek mümkün olur. illizarov prensiplerinde distraksiyon osteogenezi ile rejenerat dokusu yani yeni kemik dokusu elde edilmektedir. Bu durum açık kama osteotomilerini daha uygun hale getirmektedir. Distraksiyon osteogenezi ile elde edilen açık kama osteotomisi de iki kemik arasında rejenerat dokusu oluşacağından greft kullanmaya gerek kalmaz. Açık kama osteotomisi açısal rotasyonel translasyonel düzeltmeler sağlayabileceği gibi uzatma da sağlayacaktır. ${ }^{[5,8-10]}$

\section{OSTEOTOMI KURALLARI}

Osteotomi kuralları geometrik hesaplamalar temelinde matematiksel kavramlardır. Kurallar tanımlanırken ilizarov tipi sirküler eksternal fiksatör kullanılmasına rağmen her türlü ekstremite rekonstrüksiyon yöntemi için geçerlidir. ${ }^{[5]}$

\section{Kural 1}

Osteotomi hattı ve ACA, CORA ile aynı seviyede ise mekanik aks düzelir ve kemik uçlarında angulasyon olur. Her zaman istenilen budur, ama her zaman mümkün olamayabilir.

Osteotomi deformitenin merkezi olan CORA üzerinden yapılıyorsa ve menteşelerin hizası olan ACA doğrultusu CORA hizasında transvers açıortay çizgisi üzerinde ise bu kural gerçekleşir. Proksimal ve distal akslar düzeltme sonrası ideal bir çizgide hizalanarak tek aks oluştururlar. Böylelikle deformite düzelmiş olur. Menteşenin konveks veya konkav tarafa yerleştirilme şekli kemik uçlarında kompresyon veya distraksiyona sebep olur. Bu durum kemik boyunu değiştirir. Üç tür senaryo oluşabilir. ${ }^{[10-12]}$

1. Açık Kama Osteotomisi: Menteşenin, ACA üzerinde deformitenin konveks tarafına yerleştirilmesi ile oluşur. Kemik uçlarından CORA'nın derecesi kadar meydana gelen açılanma distraksiyona sebep olur. Kemik boyu uzar (Şekil 3).

2. Kapalı Kama Osteotomisi: Menteşe ACA üzerinde deformitenin konkav tarafına yerleştirilmesi ile oluşur. Kemik uçlarından CORA'nın derecesi kadar meydana gelen açılanma kompresyona sebep olur. Osteotomi yaparken kompresyon yapılacak yerden fragman çıkarmak gerekir. Kemik boyu kısalır (Şekil 4).

3. Nötral Kama Osteotomisi: Menteşenin ACA üzerinde tam olarak deformitenin merkezi olan CORA'dan geçecek şekilde yerleştirilmesi ile oluşur. Konkav tarafta distraksiyon ve konveks tarafta kompresyon sağlanması ile bir denge oluşur. Birbirini dengeleyen bu etkiyle kemik boyunda herhangi bir değişim görülmez (Şekil 5). 


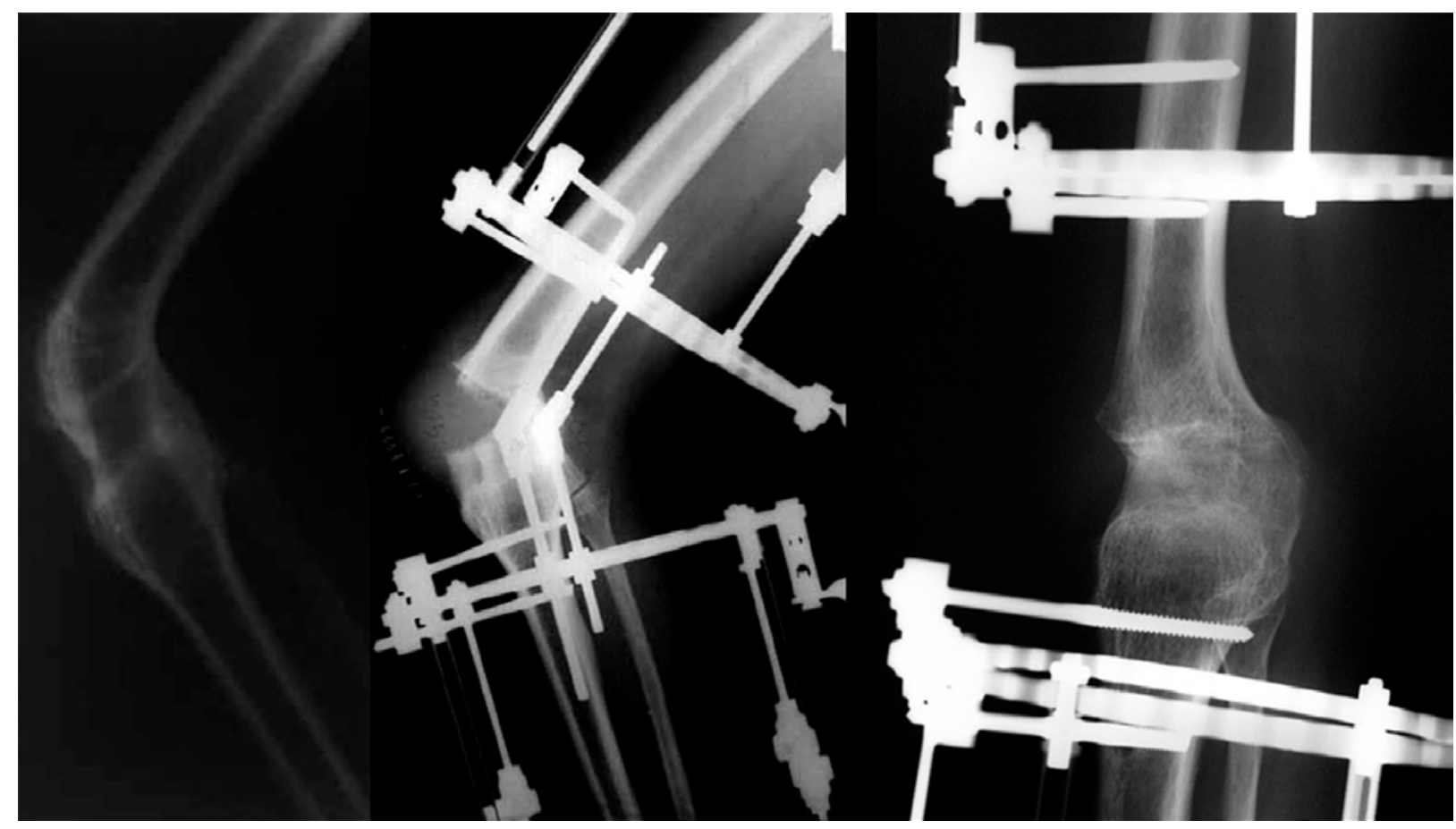

Şekil 4. Kapalı Kama Osteotomisi: Hemofilik artropati nedeni ile diz fleksiyon kontraktürü gelişen ve sonrasında bu pozisyonda ankiloze olan hastaya yapılan kapalı kama osteotomisi, çıkarılan kemik fragman sonrası lateral planda tedrici kompresyon ve sonrasında distraksiyon ile uygun pozisyonda artrodez uygulanmış. Bu düzeltmenin tedrici yapılması damar sinir yapılarının korunması için önemlidir.

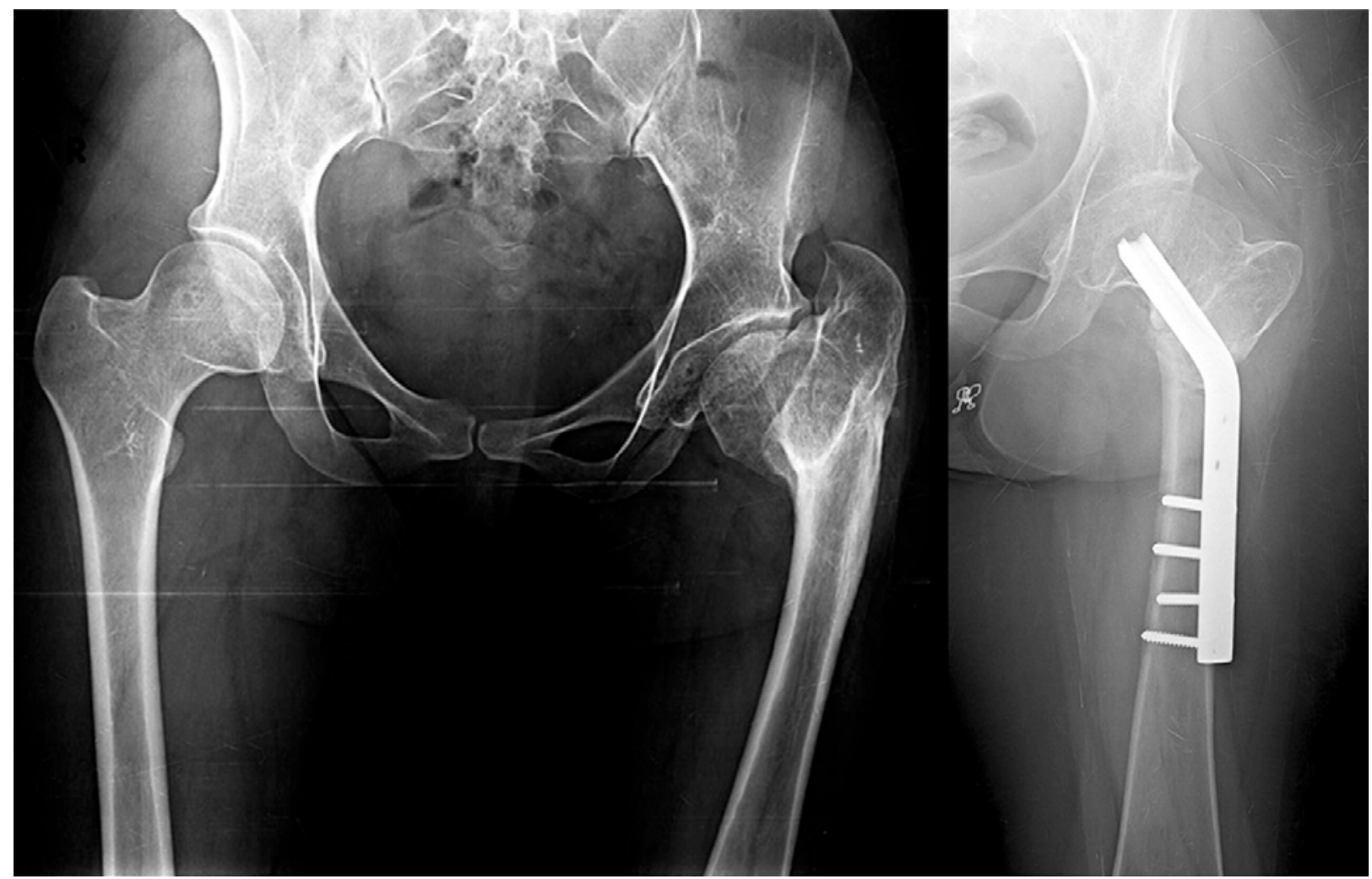

Şekil 5. Nötral Kama Osteotomisi: Kalça valgizasyon osteotomisi nötral kama osteotomisi için iyi bir örnektir. Konjenital femoral yokluk (deficiency) mevcut hastaya uzatma cerrahisi öncesi kalça valgizasyon osteotomisi ve internal tespit uygulanmıştır. Hastada kemik boyunda kısalma veya uzama olmamıştır. 


\section{Kural 2}

ACA çizgisi CORA ile aynı seviyededir. Ancak osteotomi farklı bir seviyede yapılmıştır. Genelde bu durum yumuşak dokunun osteotomi yerine izin vermediği veya eklem içi deformitelerde ve fizyel sorunlara bağlı oluşan deformitelerde ortaya çıkmaktadır. Akslar yine amaca uygun şekilde düzelir, kemik uçlarında yukarıdaki üç senaryoda olduğu gibi açılanmalar oluşur. Bunlara ek olarak kemik uçlarından translasyon meydana gelir. Bu translasyon, osteotomi farklı seviyeden yapıldığı için aksın düzelmesi için gereklidir. Eğer translasyon olmaksızın bir düzeltme elde edilirse iki farklı mekanik aksın elde edildiği deformite tekrar değerlendirildiğinde görülecektir. ${ }^{[5,10-12]}$

Kemik uçlarındaki translasyon miktarı osteotomi hattının ACA ile olan uzaklığı ile doğru orantılıdır (Şekil 6).

\section{Kural 3}

Üç numaralı osteotomi kuralı aslında istenmeyen bir durumdur. Diğer iki kuralda düzeltme sonunda aks düzelirken bu kuralda düzelme gerçekleşmez. ACA, CORA'dan değil de farklı bir yerden geçiyorsa, akslar arasında translasyon meydana gelmez. ${ }^{[10-12]}$ Menteşe yerleştirilmesinde yapılan hatalar sonucu oluşur (Şekil 7). Bu kuralın bilinmesi durumun farkedilip düzeltilmesine yardımcı olacaktır. Klinikte en sık rastlanılan hata tam olmayan proksimal tibia osteotomisi ile gözlemlenir. ${ }^{[13,14]}$ Deformite eklem içinde ise yapılan açık kama osteotomisi ile osteotomi kural 3'e sebep olunur, bu da alt ekstremitede iki farklı mekanik aks oluşmasına neden olacaktır. ${ }^{[12,14-16]}$ Bu durum dizde makaslama kuvvetlerinin artmasına sebep olur ve artrozu hızlandırır.

Osteotomi kuralları kullanılırken deformitenin CORA üzerinde, menteşe ekseninin ACA üzerinde, anatomik yapıların osteotomi üzerinde belirleyici olacağı göz önünde bulundurulmalıdır (Tablo 1).

Osteotomi kuralları anlaşıldıktan sonra her türlü düzeltme ve ekstremite rekonstrüksiyonu işlemi için kullanabilir. Düzeltme yapılırken tedrici düzeltmede, kemik dışı yapıları, damar ve sinir yapılarını korumak için günlük düzeltme miktarı hesap edilmelidir. Amaç damar ve sinir yapılarında günlük 1 mm'lik distraksiyon olacak şekilde planlamanın yapılmasıdır. Akut düzeltme yapılacak olgularda düzeltme aksının ACA'nın üzerinde bulunan damar ve sinir dokularında oluşacak düzeltme, uzama ve gerilme miktarları iyi planlanmalıdır. Örneğin diz çevresinde varus düzeltmesi arter ve sinir yapılarında önemli bir değişiklik yapmaz iken, valgus deformitesi için yapılacak varizasyon osteotomisi fibular sinirde gerilmeye neden olacaktır. Aynı şekilde diz fleksiyon kontraktürü düzeltilirken fibular ve tibial sinirlerle beraber popliteal arterde de olası riskler göz önünde tutulmalıdır. ${ }^{[14-16]}$

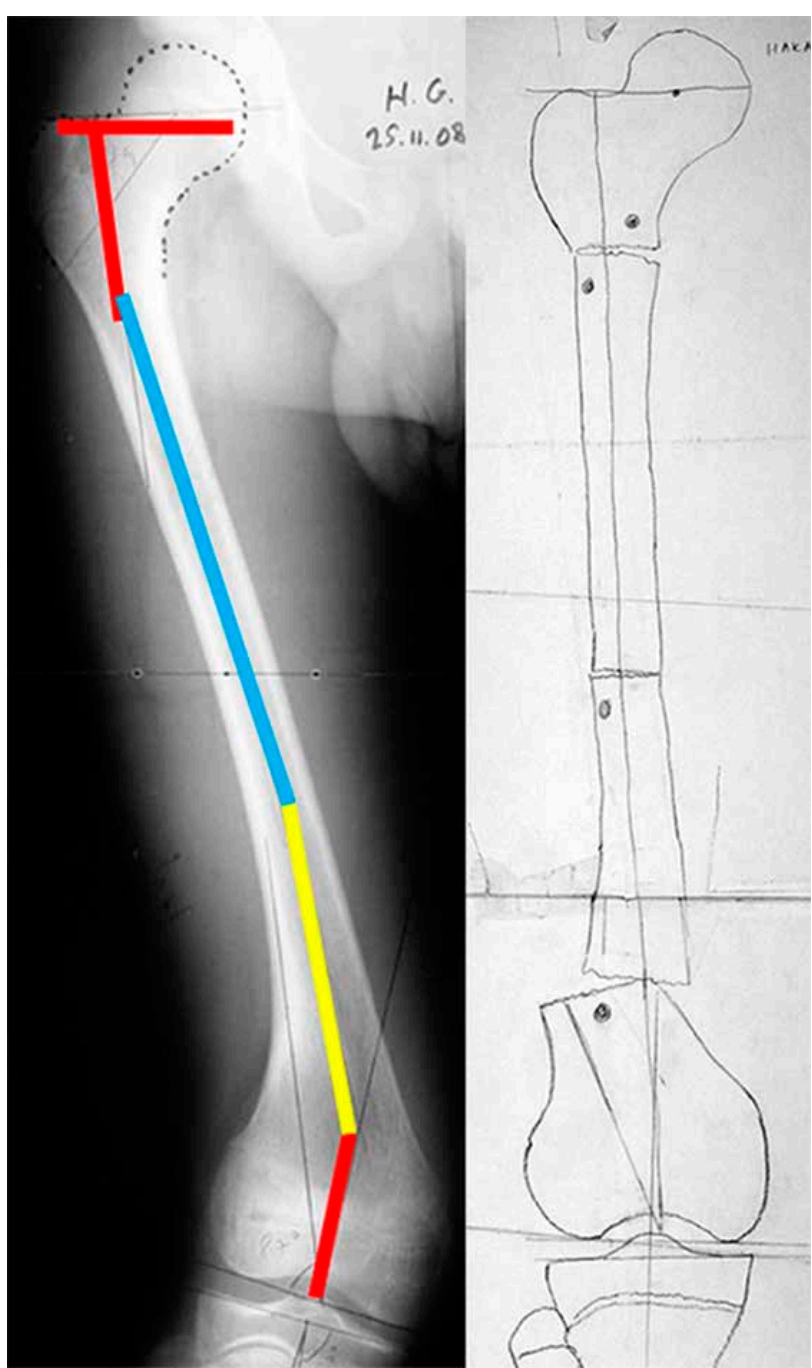

Şekil 6. Distal femurda mevcut deformite akut bir açılanmadan ziyade dairesel olarak devam etmektedir. Burada tek bir CORA yoktur sonsuz sayıda CORA mevcuttur. Özellikle deformitedeki eğrilik distale doğru artmaktadır. Fizyel bir sorun bu durumun oluşmasına neden olmuştur. Kullanılacak implanta uygun yapılacak osteotominin ameliyat öncesi çizimi ve planlamasında eklemin yere paralel hale gelmesi ve mekanik eksenlerin doğrusallığı için gereken translasyon ihtiyacı görülecektir. Translasyon ihtiyacı osteotomi yeri CORA'dan ne kadar uzakta olursa, o kadar fazla olur.

Tablo 1. Osteotomi kurallarının birbirleri ile olan ilişkileri[16]

\begin{tabular}{cccc}
\hline & CORA & ACA & Ostetotomi \\
\hline Kural 1 & Aynı & Aynı & Aynı \\
Kural 2 & Aynı & Aynı & Farklı \\
Kural 3 & Farklı & Farklı & Farklı
\end{tabular}




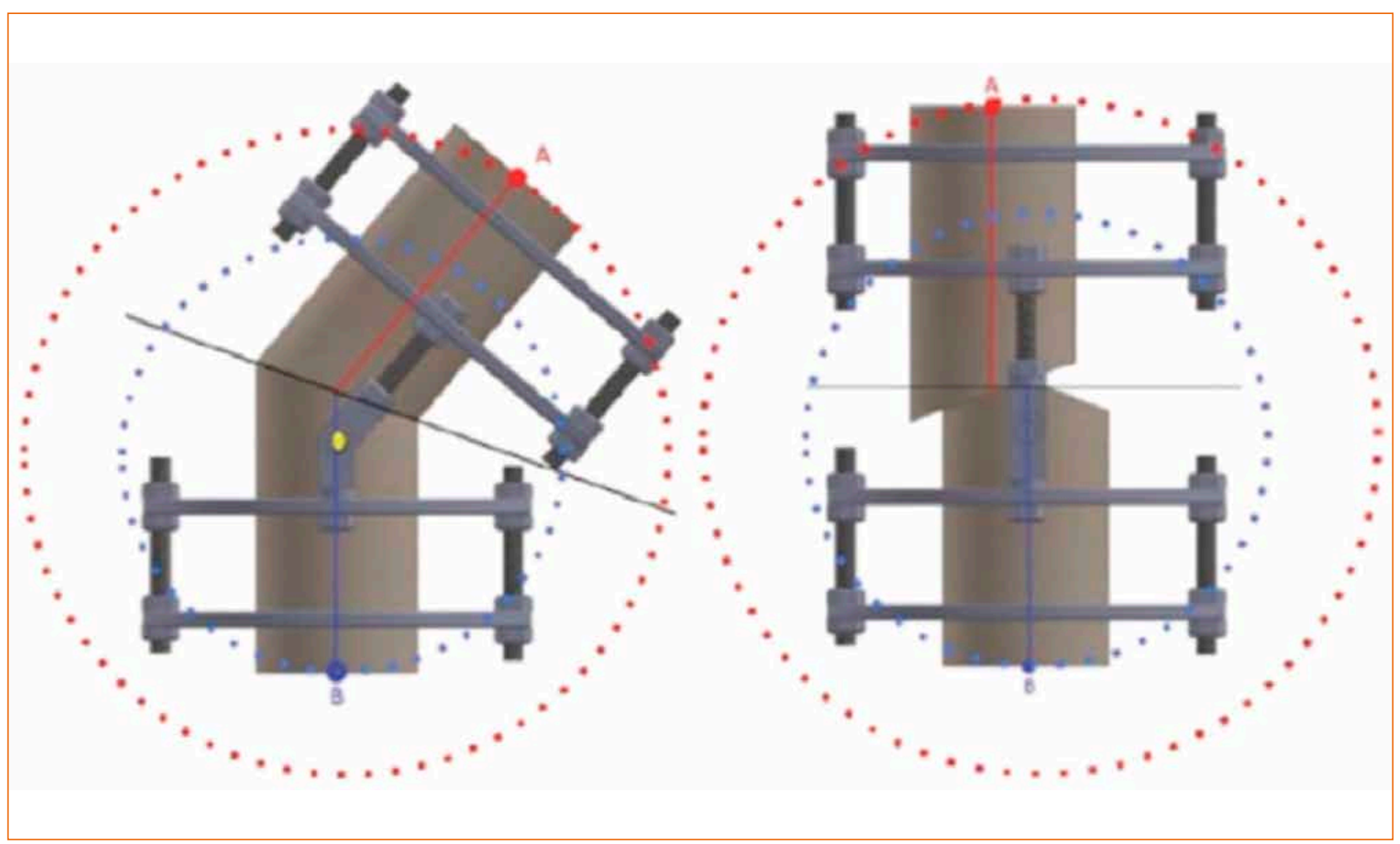

Şekil 7. ACA ve CORA farklı seviyelerde yerleştirildiğinde, ACA menteşe hizasında, CORA deformite seviyesindedir. Bu durumda deformiteye eşit uzaklıktaki iki noktanın, menteşe noktasına olan uzaklıkları farklı olacaktır.

Akut düzeltme internal tespit tercih edilen olgularda sıkça kullanılmaktadır. Intramedüller çivi ile tespit, akut düzeltmede sık kullanılan uygulamalardandır. Deformite anatomik aks üzerinden düzeltilir. Anatomik aks üzerinden yönlendirilen çivi nedeni ile, osteotomi deformitenin apeksine yakın olmak zorundadır. Aksi takdirde kullanılabilecek çivi kalınlığı translasyona bağIı olarak azalır bu stabilite sorunlarına neden olur. Bu durumlarda metafizer daraltma ve stabilite için polar vidası kullanmak gerekebilir (Şekil 8). Osteotominin konveks tarafında kemik teması olacağından, konkav tarafta distraksiyon oluşur. Yapılan açık kama osteotomisidir. Medulla içerisine çivinin gönderilmesi ile anatomik aksa zorlanır ve deformite düzeltilmiş olur. Diğer bir teknik olarak düzeltme sonrası plaklama uygulamasıdır. Düzeltmenin standart eksternal fiksatör yardımıyla tedrici veya akut olarak yapılması sonrası plak-vida ile tespit yapılarak fiksatör çıkarılır. Plak ile yapılan tespitte, ya kısaltma veya greftleme ile kemik korteksleri arasında temas elde edilmesi gerekir ya da stabilite için çift plak kullanılır. ${ }^{[16]}$
Fiksatör yardımlı çivileme anlamına gelen FAN (Fixator-Assisted Nailing) tekniğinde ise, çivileme öncesinde eklem çevresini ilgilendiren deformiteler bulunuyorsa osteotomi sonrası ekleme yakın olan fragmanların kontrolünü sağlamak ve korreksiyon kaybını önlemek amacıyla eksternal fiksatör ve çivi ardışık olarak kullanılır. ${ }^{[17]}$ FAN tekniğinin en önemli avantajı, eksternal fiksatörle sağlanan düzeltme peroperatuar olarak ayarlanabilir ve istenilen rotasyon korunur. Dezavantajı ise cerrahın eksternal fiksatörlere özellikle de monolateral fiksatörlere deformite düzeltme açısında ve de intramedüller çiviye hakim olması gerekliliğidir. Kayıcı klemplerin frontal planda sağladığı ekstra düzeltme şansı dışında, monolateral fiksatörlerle diğer planlarda yapılan düzeltmelerde shanz çivilerinin gönderilme şekli ile düzeltme miktarı belirlenmiş olur.[17] Akut düzeltmede sıra tedrici düzeltmeden farklıdır. Önce translasyon ve rotasyon sonra angülasyon düzeltilir. Aksi takdirde kemikler birbirine kitlenir ve ekstra düzeltmeye izin vermez. Küçük insizyonlarla yapılan bir cerrahidir. İntramedüller çivi kullanımı plaklara göre daha stabil bir tespit sağlarken oyma işlemi sırasında otogrefonaj elde edilmiş olunacaktır (Şekil 9). 


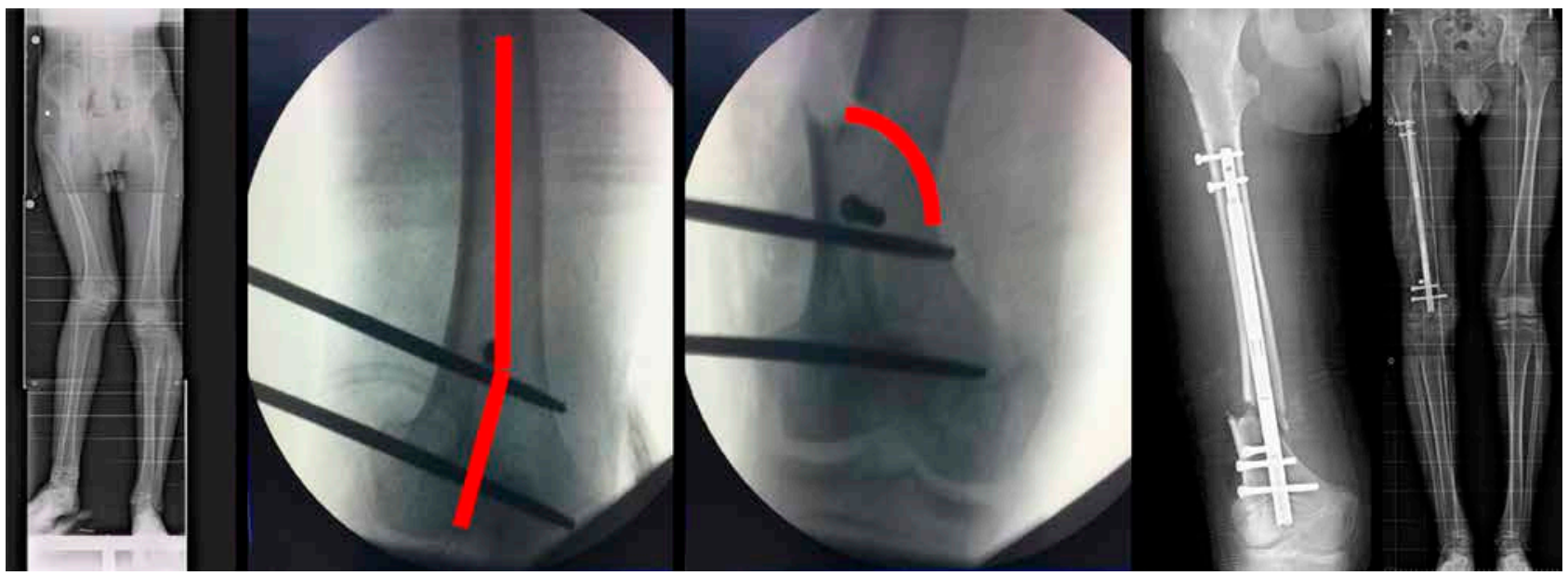

Şekil 8. Sağ alt ekstremite femur distal fiz yaralanmasına bağlı valgus deformitesi ve kısalığı olan hastanın proksimal ve distal anatomik aksı (intramedüller çivi yolu) görülmektedir. Hastanın fiz yaralanmasına bağlı gelişen deformitesinde gerçek CORA'sı eklem üzerindedir. Hastaya FAN tekniği ile akut düzeltme ve manyetik uzayabilen çivi ile aynı seansta uzatma planlandığı için çivinin distal tespitine izin verebilmesi amacı ile osteotomi CORA dışı yapılmış, oluşacak translasyonun miktarını azaltmak adına dome osteotomisi tercih edilmiştir. Metafizer osteotomi sonrası diafize oturacak intramedüller çivinin metafizde instabilitesini önlemek için intramedüller kanal konveks tarafa uygulanan polar vidası ile daraltılmıştır. Uzatma sonrası hastanın valgus ve kısalık deformitesinin düzeldiği görülmektedir. Valgus deformitesinde fibular sinir gevşetmesi rutin yapılmaktadır.
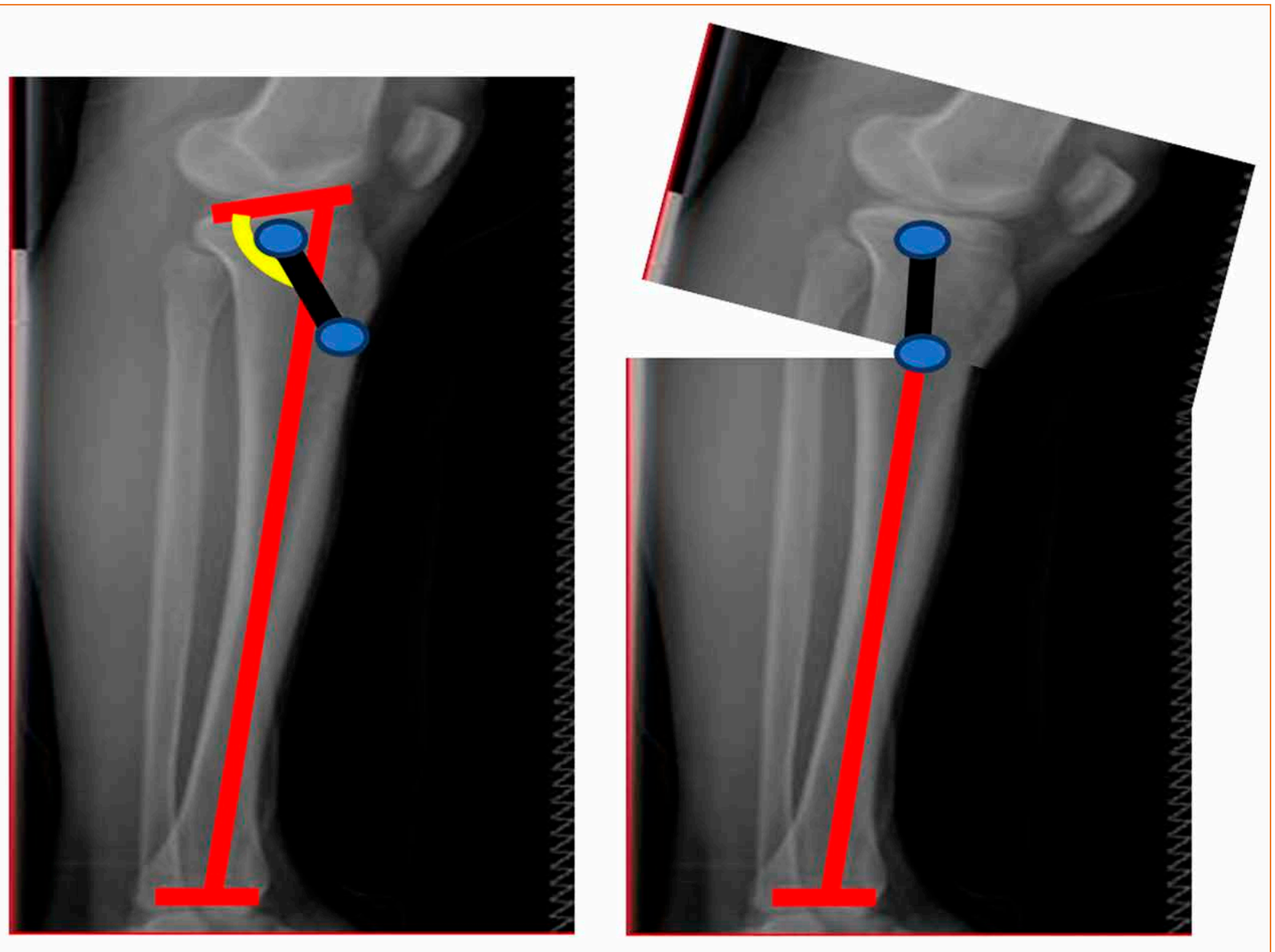

Şekil 9. Tibia proksimalinde mevcut olan prokurvatum deformitesini monolateral fiksatörle düzeltmek için shanz çivilerinin yönlendirme aksları şekilde görülen mavi noktalar gibi olmalıdır. 


\section{MENTEŞE YÖNTEMLERI}

ilizarov yönteminde kullanılan menteşeler deformitenin düzeltilmesi aşamasında bize birtakım faydalar sağlar.

- Fiksatör üzerinde tek eksende harekete izin verirler ve somunlarının sıkılmasıyla da hareket sınırlandırilır.

- Angülasyonların düzeltilmesinde destek noktasıdırlar.

- Fiksatörlerin biyolojik olarak dokuya adaptasyonunu kolaylaştırmada yardımcıdırlar.

- Eklem hareketlerine izin verirler.

Menteşeler iki parçadan oluşurlar. Her bir parça aynı mekanizmaya sahiptir ve rotasyon merkezinde bir eksende harekete izin verirler. ${ }^{[18]}$

\section{Yarım Menteşeler}

Menteşe parçaları uç kısımlarına göre dişi ve erkek olarak adlandırılırlar. Üzerinde cıvata bulunursa erkek, somun bulunursa dişi olarak belirtilir. Menteşeler; erkek-erkek, dişi-dişi, erkek-dişi olarak oluşturulabilir (Şekil 10). ${ }^{[18]}$

\section{Postlar}

Yarım menteşeler gibidir. Dişi ve erkek parçaların kombinasyonları ile oluşturulabilirler. Bir menteşe oluşturmak için iki yarım menteşe kullanıldığında, dişli uç veya delik aynı çizgide hizalanır (Şekil 11). Bir menteşe oluşturmak için iki direk kullanıldığında, dişli uç veya delik aynı çizgide aynı hizada olamaz. Bu iki menteşe türü angulasyon varsa kullanılabilir. ${ }^{[18]}$

\section{Plaklar}

Başka bir menteşe tipi iki plak, bir somun ve bir cıvata ile oluşturulabilir (Şekil 12). ${ }^{[14,18]}$

\section{Çok Eksenli Menteşeler}

Yukarıda tek bir hareket düzlemine sahip tek eksenli menteşelerden bahsedildi, ancak gerektiğinde çoklu dönme merkezlerine sahip çok eksenli (poliaksiyel) menteşeler oluşturmak mümkündür (Şekil 13). Bunu yapmak için, üç veya daha fazla yarım menteşenin bir araya getirilmesi gerekir. Menteşede hareketi sağlamak için teflon somun kullanılmalıdır. ${ }^{[12,14,18]}$

\section{Kişiye Özel Çift Eksenli Menteşe}

Kişiye özel menteşeler, tek bir sistemde iki dik hareket ekseninin kullanımı için özel olarak üretilmiştir (Şekil 14). Ayrıca ek menteşelerle değiştirilebilir ve poliaksiyel bir menteşeye dönüştürülebilir.

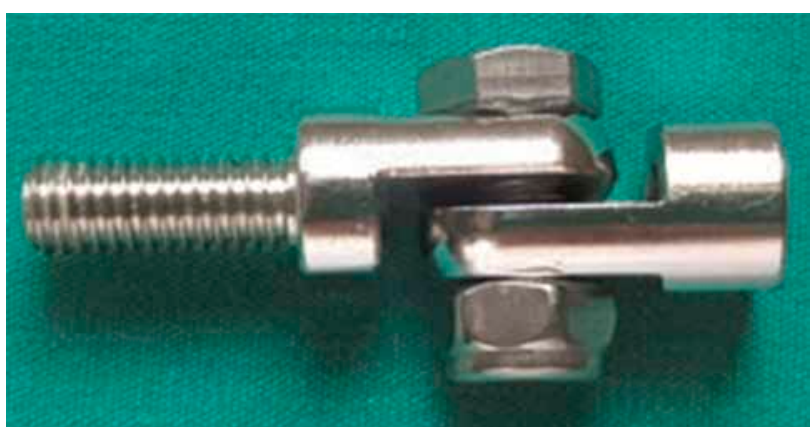

Şekil 10. Bir dişi ve bir erkekten oluşan yarım menteşe.

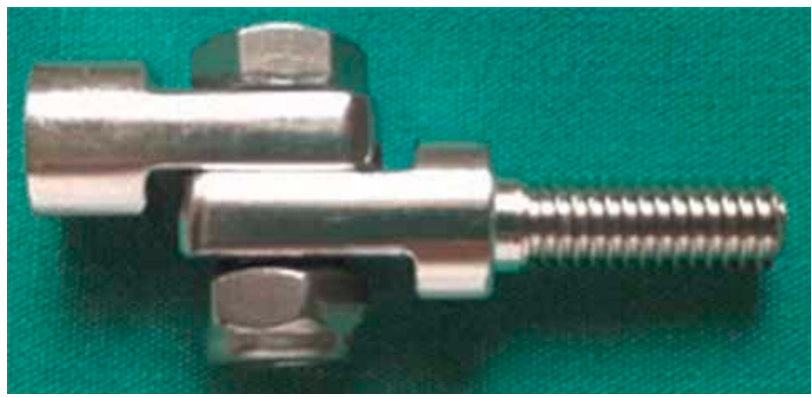

Şekil 11. Bir dişi ve bir erkekten oluşan tam menteşe.

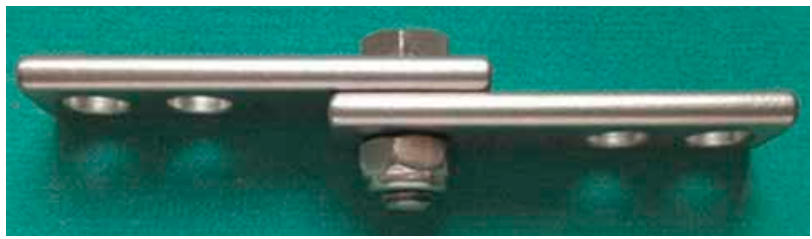

Şekil 12. Plaklardan oluş̧turulmuş menteşe.

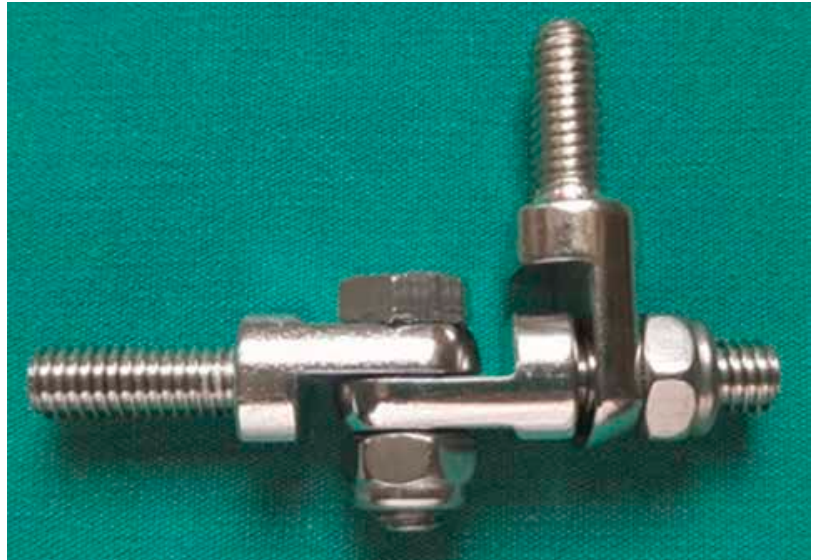

Şekil 13. Poliaksiyel menteşe.

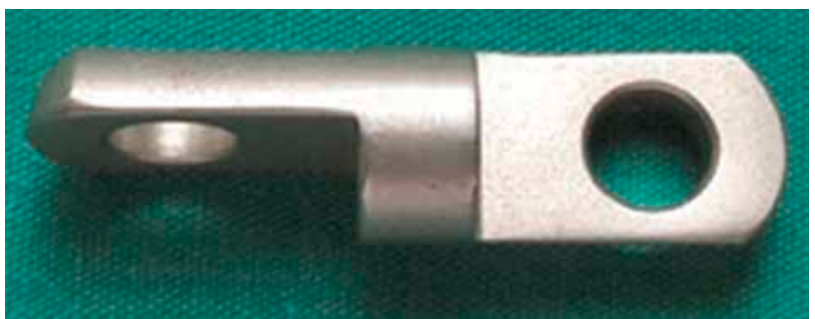

Şekil 14. Kişiye özel üretilmiş menteşe. 


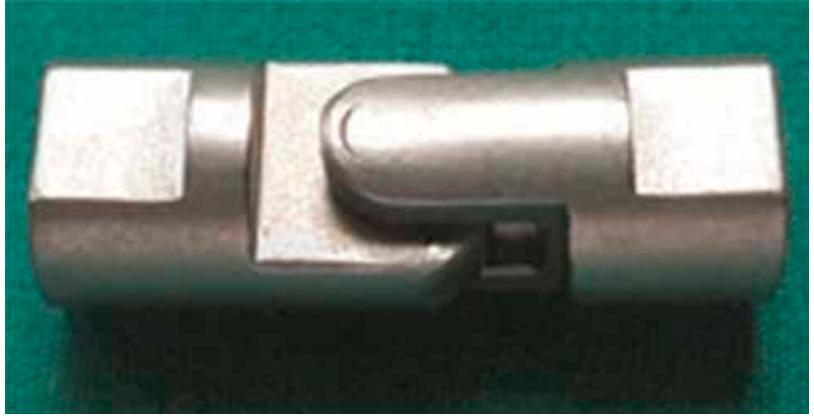

Şekil 15. U menteşe.

İki eksenin her yöne hareket edebilmesi gerektiğinden, bir "U" menteşe (Universal menteşe) mevcuttur (Şekil 15). Bu menteşeler, eksensel şekil bozukluklarında veya eklemlerde harekete izin vermek için kullanılır. " $U$ " menteşeler sisteme dişli çubuklarla bağlanır. ${ }^{[12,14]}$

\section{MENTEŞE KONUMLANDIRMA ILKELERI}

1. Menteşeye bağı halkalar kemiklere dik olarak yerleştirilir.

2. Menteşenin dönme merkezi deformitenin apeksinde olmalıdır.
3. Deformitenin düzeltme düzlemi menteşelerle aynı düzlemde olmalıdır.

4. Menteşeler aynı yatay seviyede olmalıdır.

5. Stabilite için en az iki menteşe birbirine bakacak şekilde yerleştirilmelidir.

6. Ayarlanabilir menteşelerin konumları sayesinde farklı düzeltmeler yapılabilir. Bu düzeltmeler açık kama, kapalı kama, nötral kama, kompresyon, distraksiyon ve rotasyondur. ${ }^{[14,18]}$

\section{Ekleme Menteşe Yerleştirilmesi}

Eklem kontraktürlerinin tedrici düzeltilmesinde ilizarov tipi eksternal fiksatörlerin önemli avantajları vardır. Tedrici düzeltme ile damar sinir yapılar korunurken konulan menteşe yardımı ile eklemin sublukse olması özellikle konjenital anomalilerde engellenmiş olur. Ekleme hareketli bir menteşe uygularken eklemin uzayda yaptığı üç boyutlu hareketi esas olarak iki boyuta indirgemiş oluruz. Bu sebeple her ekleme uygun menteşe yerleştirme noktaları tanımlanmıştır. Örneğin; diz ekleminde bu nokta posterior korteks çizgisi ile distal femur fizinin lateral grafide kesişme hattının önüne ve üstüne denk gelmektedir. Her kişi için bu nokta değişmekle beraber cerrahide eklemin rahat hareket ettiği görülerek yerleştirilmelidir (Şekil 16). ${ }^{[19]}$
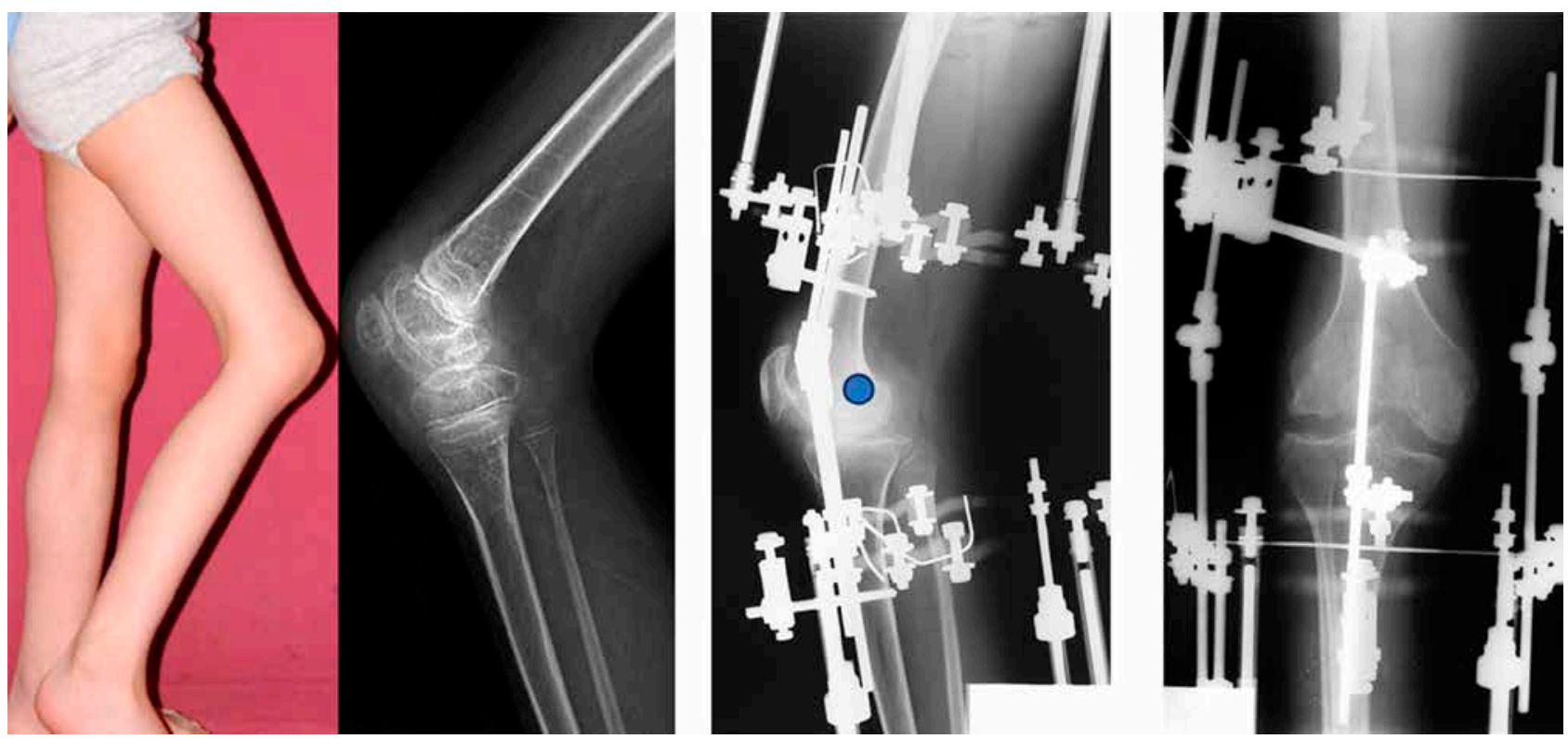

Şekil 16. Hemofilik artropatiye bağlı dizde gelişen diz fleksiyon kontraktürünün tedrici olarak düzeltilmesi. Burada lacivert ile gösterilen nokta diz ekleminde izometrik noktayı tarif etmektedir. Eğer amacımız bir uzatma cerrahisi sırasında veya bir travmada diz ekleminin hareketine izin vererek luksasyonuna engel olmak olsaydı menteşemizi buraya yerleştirip hastaya 0-90 derece hareket çalıştırabilirdik. Ancak bu olguda amacımız eklemde düzeltme sırasında kıkırdak dokuda oluşacak basıncı ve kondropatiyi önlemek olduğu için menteşemizi ACA üzerinde deformitenin konkav tarafına motor ünitemizi de posteriora yerleştirerek eklemde hem distraksiyon hem de düzeltme elde etmiş oluruz. ${ }^{[19]}$ 


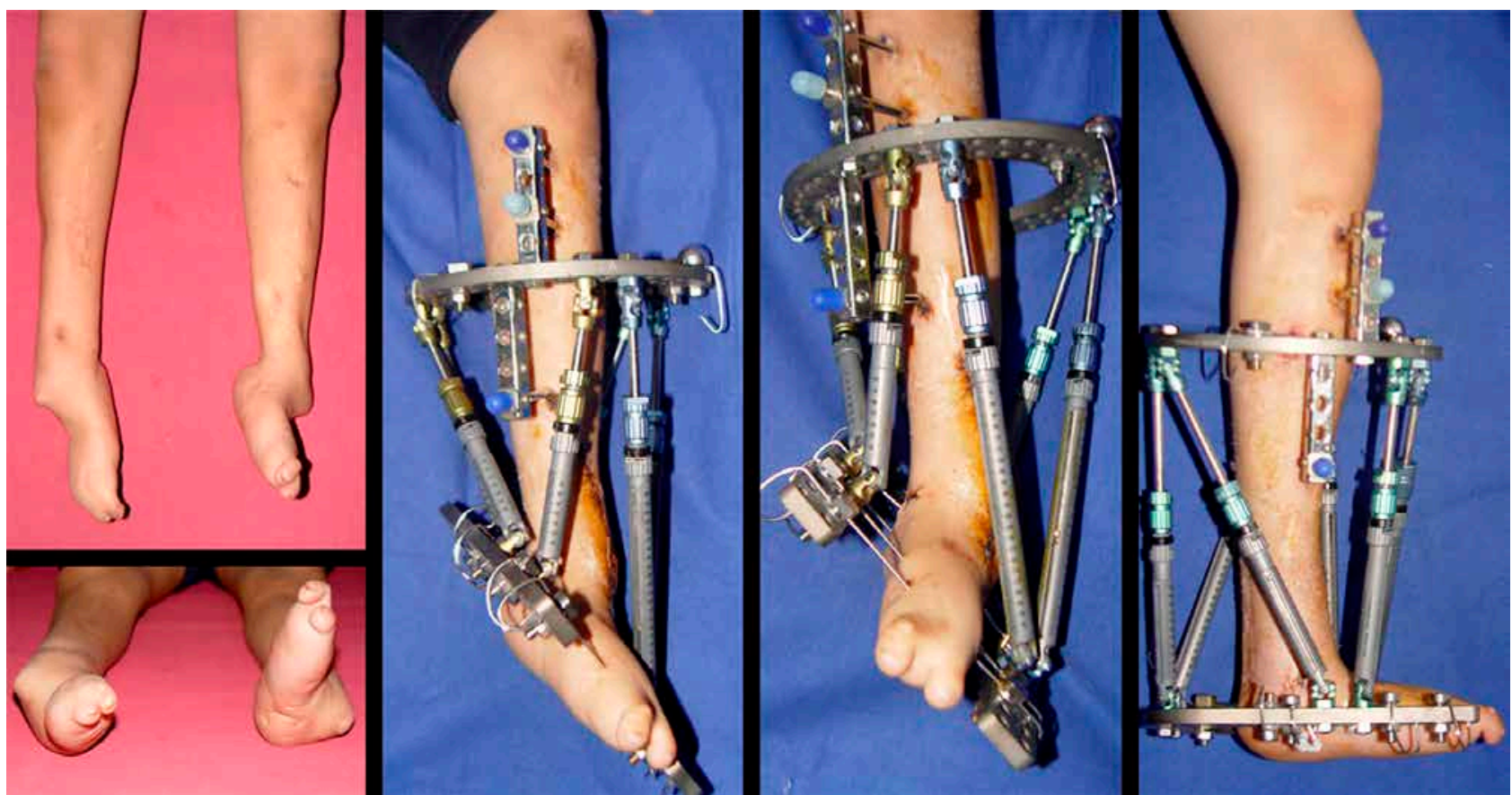

Şekil 17. Tibial hemimeli vakasında ayağın distal fibulaya santralizayonu üç boyutta bir düzeltme ve yumuşak doku distraksiyonu gerektirmektedir. Aynı işlem klasik ilizarov yöntemleri ile de yapılabilirdi, ancak bu durumda çok tecrübeli ellerde menteşe yerleştirilmesi veya birkaç menteşe revizyonu göze alınması gerekmekte idi.

\section{Uzaysal Menteşe}

Uzaysal fiksatörlerin kullanılması ile artık düzeltmeler uzaydaki menteşe üzerinden üç boyutlu olarak kullanılan yazılım (software) özelliklerine göre yapılmaktadır. Ancak klasik menteşe eğitimi almadan bu sistemlerin kullanılması özellikle komplike vakalarda sorun oluşturmaktadır. Bu yöntemlerde menteşenin yapacağı angulasyon dışında düzeltme ile oluşması gereken distraksiyon ve translasyon hesaplanarak bilgisayar programına hesaplamalar girilmelidir. Referans halkaya göre istenilen düzeltme yazılım ortamında doğru hesaplanırsa oluşacak program doğru olacaktır. Altı çubuklu (bacaklı) bu heksapod sistemlerde yüksek oranda rotasyon ve translasyon düzeltilmesi sıkıntılı olabilir. Bu durumlarda cerrahi sırasında akut kısmi rotasyon düzeltilmesi veya geniş halkaların tercih edilmesi gerekebilir. Yapılacak düzeltme sadece kemik dokuda değil tibial hemimelili (Şekil 17) olgularında sıkça kullandığımız gibi yumuşak dokuda da yapılabilir. Özellikle üç boyutlu düzeltme yapılması gereken olgularda uzaysal fiksatörler önemli avantajlar sağlar. ${ }^{[20]}$

\section{KAYNAKLAR}

1. Golyakhovsky V, Frankel VH. Operative Manual of Ilizarov Techniques. St. Louis: Mosby; 1992. p.2.
2. Herzenberg JE, Waanders NA. Calculating rate and duration of distraction for deformity correction with ilizarov technique. Orthop Clin North Am 1991;22(4):601-11.

3. Lavelle DG. Chapter 52: Delayed union and pseudoarthrosis of fractures. In: Campbell's Operative Orthopedics, 9th ed; CV. Mosby. Co Publishing, St. Louis 1998. p.2595-9.

4. Maiocchi $\mathrm{AB}$, Aronson J. Operative Principles of Ilizarov, ASAMI. Baltimore: Williams \& Wilkins; 1991. p.4.

5. Paley $\mathrm{D}$. The principles of deformity correction by the llizarov technique: technical aspects. Tech Orthop 1989;4(1):15-29. Crossref

6. Paley D, Maar DC, Herzenberg JE. New concepts in high tibial osteotomy for medial compartment osteoarthritis. Orthop Clin North Am 1994;25(3):483-98.

7. Paley D, Tetsworth K. Percutaneous osteotomies. Osteotome and Gigli saw techniques. Orthop Clin North Am 1991;22(4):613-24.

8. Catagni MA. Current trends in the treatment of simple and complex bone deformities using the llizarov method. Instr Course Lect 1992;41:423-30.

9. Paley D, Herzenberg JE, Tetsworth K, McKie J, Bhave A. Deformity planning for frontal and sagittal plane corrective osteotomies. Orthop Clin North Am 1994;25(3):425-65.

10. Paley D. Principles of Deformity Correction, 3rd ed. Berlin: Springer Verlag; 2005.

11. Paley D, Tetsworth K. Mechanical axis deviation of the lower limbs. Preoperative planning of multiapical frontal plane angular and bowing deformities of the femur and tibia. Clin Orthop Relat Res 1992;(280):65-71. Crossref 
12. Çakmak MB, Kocaoğlu M, editors. Illizarov Cerrahisi ve Prensipleri. İstanbul: Doruk Grafik; 1999.

13. Hankemeier S, Paley D, Pape HC, Zeichen J, Gosling T, Krettek C. Knee paraarticular focal dome osteotomy. Orthopade 2004;33(2):170-7. Crossref

14. Çakmak MÖ, Şen C, editors. Travmada İlizarov Uygulamaları. İstanbul: İklim Matbaa; 2013.

15. Maquet P. Valgus osteotomy for osteoarthritis of the knee. Clin Orthop Relat Res 1976;(120):143-8. Crossref

16. Uysal M, Akpinar S, Cesur N, Hersekli MA, Tandoğan RN. Plating After Lengthening (PAL): technical notes and preliminary clinical experiences. Arch Orthop Trauma Surg 2007;127(10):889-93. Crossref
17. Kocaoglu M, Eralp IL, Bilen FE, Balci HI. Fixator assisted acute femoral deformity correction and consecutive lengthening over an intramedullary nail. J Bone Joint Surg Am 2009;91(1):152-9. Crossref

18. Çakmak M, Şen C, Eralp L, Balcı Hi, Civan M, editors. Basic Techniques for Extremity Reconstruction. External Fixator Applications According to Ilizarov Principles. Switzerland: Springer; 2018.

19. Balci HI, Kocaoglu M, Eralp L, Bilen FE. Knee flexion contracture in haemophilia: treatment with circular external fixator. Haemophilia 2014;20(6):879-83. Crossref

20. Balcı Hi, Sağlam Y, Bilgili F, Şen C, Kocaoğlu M, Eralp L. Preliminary report on amputation versus reconstruction in treatment of tibial hemimelia. Acta Orthop Traumatol Turc 2015;49(6):627-33. Crossref 